\title{
Copepod gut contents, ingestion rates and grazing impact on phytoplankton in relation to size structure of zooplankton and phytoplankton during a spring bloom
}

\author{
B. Bautista*, R. P. Harris \\ Plymouth Marine Laboratory, Prospect Place, Plymouth PL1 3DH, UK
}

\begin{abstract}
Copepod gut contents, ingestion rates as well as the grazing impact on phytoplankton were estimated in coastal waters off Plymouth (SW England) before and during the spring phytoplankton bloom in 1989. A size-fractionation approach was applied, estimating phytoplankton biomass as chlorophyll a concentration in 3 size fractions [pico- $(0.2$ to $2 \mu \mathrm{m})$, nano- $(2$ to $10 \mu \mathrm{m})$ and microplankton $(10$ to $100 \mu \mathrm{m})]$ and copepod abundances, gut pigment contents and gut evacuation rates in 3 size categories (small, 200 to $350 \mu \mathrm{m}$; medium, 350 to $710 \mu \mathrm{m}$; and large, $>710 \mu \mathrm{m}$ ). Results showed a direct relation between copepod feeding and the size structure of zooplankton and phytoplankton. Gut pigment contents were higher for the larger copepods and lower for the smaller ones, and increased in parallel with the increase of chlorophyll a concentration and dominance of large cells (>10 $\mu \mathrm{m}$ ) during the spring bloom. Estimations of the grazing impact of the copepod community showed that 5 to $8 \%$ of the total phytoplankton standing stock, and up to between 30 and $40 \%$ of the fraction $>10 \mu \mathrm{m}$, was grazed during the exponential growth phase of phytoplankton prior to the spring bloom, in contrast to $<2 \%$ and $<5 \%$, respectively, during other periods before and after the bloom. The medium-sized copepods were responsible for most of this grazing impact, as a result of their numerical dominance in these coastal waters. Different aspects affecting these estimations of copepod community grazing impact are discussed.
\end{abstract}

\section{INTRODUCTION}

This study was carried out in spring 1989 in coastal waters off Plymouth (SW England), analysing the coupling of the temporal variation in phytoplankton biomass and size distribution before and during the spring bloom with the functional and numerical responses of copepods, with respect to their ingestion rates, abundances and grazing impact on phytoplankton. During this study, a particular hypothesis was tested concerning events at the base of the food webs. It was suggested that in coastal waters, after periods of rough weather with vertical mixing of the water column, short-term reductions in such mixing might result in brief blooms of phytoplankton of larger cell size, and

\footnotetext{
- Present address: Departamento de Ecologia, Facultad de Ciencias, Universidad de Málaga, Campus de Teatinos, E-29071 Málaga, Spain
}

this in turn might result in increased copepod feeding and ingestion rates.

It is known that temporal and spatial variability in the water column structure, resulting from vertical mixing processes and subsequent input of nutrients to the photic zone, may give rise to phytoplankton blooms. Such blooms are characterized by large-sized cells (mainly diatoms), while small-sized cells (flagellates and cyanobacteria) generally dominate the phytoplankton community between mixing events and in more permanently stratified oligotrophic waters (Legendre 1981, Holligan et al. 1984, Harris et al. 1987). Such variability in phytoplankton composition and size distribution is known to occur at oceanwide and seasonal scales (Cushing 1989), as well as on much finer temporal or spatial scales, e.g. in association with windor upwelling-generated vertical mixing events (Kiørboe et al. 1990, Nielsen \& Kiørboe 1991).

The fate of the phytoplankton biomass in the pelagic food web depends strongly on its size structure. Small 
phytoplankton cells $(<10 \mu \mathrm{m})$ may be ingested by protozooplankton and microzooplankton, supporting a long 'microbial'-type food web with many trophic levels. Large phytoplankton cells $(>10 \mu \mathrm{m})$, on the other hand, are more likely to be ingested by copepods, supporting a short 'classical type food web (Landry 1977, Frost 1984, Fenchel 1988, Kiørboe et al. 1990).

In the present study we investigated the changes in the trophic environment (phytoplankton biomass and cell size) before and during a spring bloom and their effects on feeding and grazing rates of the copepod community. A size approach was used for phytoplankton and zooplankton analysis. Many authors have reported a direct relationship between phytoplankton cell size and copepod feeding. Copepods feed inefficiently on particles < 10 um (Bartram 1980, Peterson \& Bellantoni 1987) and show a preference for particles larger than 5 to $10 \mu \mathrm{m}$ (Harris 1982, Paffenhofer 1984, Berggreen et al. 1988, Dam \& Peterson 1991). Therefore, 3 phytoplankton size fractions were considered: $0.2-2,2-10$ and $>10 \mu \mathrm{m}$. On the other hand, several studies have shown a direct relation between copepod body size and feeding rates (Peters \& Downing 1984 , Morales et al. 1990). Thus, 3 copepod size categories were considered: small (200 to $350 \mu \mathrm{m}$ ), medium (350 to $710 \mu \mathrm{m})$ and large $(>710 \mu \mathrm{m})$. In each size category, the gut pigment contents, gut evacuation rates, abundances and grazing impact on phytoplankton were estimated.

The gut fluorescence method (Mackas \& Bohrer 1976) was applied to estimate gut pigment contents and ingestion rates of the copepod community. This method has been used increasingly over the last decade to estimate ingestion rates in situ on different copepod species (reviewed in Morales et al. 1990). Comparisons with direct measurements of ingestion rates by other methods have yielded similar values (Baars \& Oosterhuis 1984, Kiørboe et al. 1985, Peterson et al. 1990a). Although this method has been criticized for not fulfilling some of its assumptions (Wang \& Conover 1986, Lopez et al. 1988, Dam et al. 1991), it is still simple and reliable for use in field studies, and seems to be adequate when the limitations are taken into account (Head 1986, Bautista et al. 1988, Peterson et al. 1990a). Its application to copepod size fractions has been previously analysed (Morales et al. 1990, 1991) showing the practical advantage of this approach; it is simpler and more widely applicable to studies involving variable temporal and spatial scales, and it allows for simultaneous consideration of different species and developmental stages.

Finally, the estimated ingestion rates, combined with estimates of copepod community abundances and in situ phytoplankton biomass in the different size fractions, were used to calculate the grazing impact of the copepod community on phytoplankton stock before and during the spring bloom.

\section{METHODS}

Sampling. Samples were taken weekly during the daytime at a permanent station (L4; 50 $15^{\circ} \mathrm{N}$, $48^{\circ} 13^{\prime} \mathrm{W}$ ) in the English Channel, from February 27 to May 22, 1989. At each sampling, the temperature of the photic layer was recorded and water samples were taken for chlorophyll a analysis, using a Niskin bottle at 3 depths: 10,20 and $40 \mathrm{~m}$. Three quantitative zooplankton samples were also taken for copepod gut pigment content analysis and estimation of copepod abundances. When gut evacuation experiments were carried out, additional qualitative samples of zooplankton were taken, as well as surface seawater for the incubations. Zooplankton quantitative samples were collected with WP-2 nets ( $200 \mu \mathrm{m}$ mesh) by means of vertical gentle tows from $50 \mathrm{~m}$ to the surface. After retrieval, the contents of 2 of these tows were preserved in $5 \%$ buffered formalin and used for analysis of species and abundances. The contents of a third tow were immediately poured into a soda water solution $(1 / 5 \mathrm{v} / \mathrm{v})$ to anesthetise the copepods (Kleppel et al. 1988, Morales et al. 1990) and then quickly fractionated in the 3 size categories (small (200 to $350 \mu \mathrm{m}$ ), medium $(350$ to $710 \mu \mathrm{m})$, large $(>710 \mu \mathrm{m})]$, which were rinsed with filtered seawater, concentrated onto GF/C filters and frozen $\left(-20^{\circ} \mathrm{C}\right)$ until analysed. Soda water at this concentration does not affect gut pigment measurements for short periods $(<1 \mathrm{~h})$ (Morales et al. 1990) Qualitative zooplankton samples were collected by means of short gentle oblique tows from $50 \mathrm{~m}$ to the surface with Bongo nets of 200,350 and $710 \mu \mathrm{m}$ mesh size, provided with non-filtering cod-ends to prevent damage to the copepods. These samples were immediately poured into buckets filled with seawater and transported quickly to the laboratory, protected from sunlight and cooled with circulating surface clear water.

Phytoplankton biomass and size fractions. Phytoplankton biomass was estimated as total chlorophyll a concentration and in 3 size fractions by fractionated filtering: picoplankton (0.2 to $2 \mu \mathrm{m})$, nanoplankton (2 to $10 \mu \mathrm{m})$ and large phytoplankton (10 to $100 \mu \mathrm{m}$ ). For each fraction and at each depth, $50 \mathrm{ml}$ of seawater were filtered through Nuclepore filters of the respective pore diameter and immediately frozen $\left(-20^{\circ} \mathrm{C}\right)$ until analysed. Duplicates were done for each fraction and depth. After extraction overnight in $90 \%$ acetone at $5^{\circ} \mathrm{C}$ in the dark (Strickland \& Parsons 1972), chlorophyll a fluorescence in the acetone extract was measured before and after acidification in a PerkinElmer 3000 Spectrofluorometer 
Copepod abundances. Estimates of copepod abundance were made by dividing the quantitative samples with a Folssom splitter and counting them under a dissecting microscope. Among all the copepod species in these samples, only those known from the literature to be 'potentially herbivorous' were considered as grazers, and these were counted in 2 replicate samples. Copepod numbers were transformed to abundance per $\mathrm{m}^{3}$ and distributed among the 3 size fractions.

Copepod gut pigment contents and ingestion rates. Gut pigment contents of copepods were analysed fluorometrically, following the method of Mackas \& Bohrer (1976) with the modifications and simplifications proposed by Morales et al. (1990). These mainly affect the non-homogenization of the samples and noncorrection for background fluorescence and pigment destruction in copepod guts. The analyses were performed for the 3 copepod size fractions. In each one, the dominant 'potentially herbivorous' species were selected for gut pigment analysis under a dissecting microscope at low light. Between 10 and 100 copepods per sample (depending on their size) were taken from the frozen filters, and 3 replicates were processed for each analysis. They were rinsed with filtered seawater and placed in tubes with $10 \mathrm{ml} 90 \%$ acetone overnight at $5{ }^{\circ} \mathrm{C}$ in the dark. Extracts were then analysed fluorometrically in a Perkin-Elmer 3000 Spectrofluorometer before and after acidification.

Gut pigment content was expressed as ng chlorophyll a copepod ${ }^{-1}$, obtained from the addition of chlorophyll $a$ and phaeopigment (pheophorbide expressed as chlorophyll a equivalent) concentrations in the guts. These gut pigment contents were transformed into ingestion rates using the expression:

$$
l=G \cdot k
$$

in units of ng chlorophyll a copepod ${ }^{-1} \mathrm{~d}^{-1}$, where $G=$ mean gut pigment content per copepod and $\mathrm{k}=$ the gut clearance rate constant.

To calculate the gut clearance rate constant, copepods of each size fraction were incubated separately in three $9 \mathrm{l}$ carboys filled with filtered seawater (Whatman GF/C), taking aliquots every 3 to $5 \mathrm{~min}$ for up to $1 \mathrm{~h}$. This time allowed for complete gut clearance. Three clearance experiments were done for each copepod size fraction; these were carried out in the laboratory after acclimatation of the copepods for at least $24 \mathrm{~h}$ at constant temperature $\left(15^{\circ} \mathrm{C}\right)$ under a $12 \mathrm{~h}: 12 \mathrm{~h}$ light-dark cycle. Just before each experiment, copepods were starved in filtered seawater overnight and then fed for $1 \mathrm{~h}$ with cultured phytoplankton at a non-limiting concentration, so that their guts were initially full. During the experiments every sampled aliquot was immediately sieved through the corresponding mesh size $(200$, 350 and $710 \mu \mathrm{m})$, rinsed briefly with filtered seawater. concentrated onto GF/C filters and frozen until fluorescence analysis, as described above.

Gut clearance rate constants were estimated from the relationship

$$
G_{1}=G_{0} e^{-k t}
$$

(where $G_{t}=$ mean gut pigment content per copepod at time $t_{i}$ and $G_{0}=$ initial mean gut pigment content per copepod) by exponential fits of the data for the periods of time over which the semi-logarithmic plots of data were linear and gut pigment content decreased to ca $10 \%$ of the initial value (Kiørboe \& Tiselius 1987, Dam \& Peterson 1988). Longer periods of time tend to result in underestimation of gut clearance rates (Bautista et al. 1988, Peterson et al. 1990a). An average value for $k$ was calculated for each copepod size fraction and was corrected for in situ temperature at each sampling time using a $Q_{10}=2.24$ (Dam \& Peterson 1988, from the exponential model).

Copepod grazing impact. To estimate the grazing impact of copepods on phytoplankton in the water column $(50 \mathrm{~m})$, total ingestion rate for each copepod size fraction was calculated and then related to the phytoplankton standing stock in the water column, both as total chlorophyll a concentration and in the fraction $>10 \mu \mathrm{m}$. In order to determine this, the individual ingestion rates of the dominant 'herbivorous' copepods in each size fraction were multiplied by the herbivorous copepod abundances in that size fraction, assuming that copepods of similar body size under the same environmental conditions have similar ingestion rates (Morales et al. 1990).

\section{RESULTS}

\section{Hydrography and phytoplankton}

Late winter and early spring were characterized by periods of very strong winds which continued intermittently until late April and delayed the spring bloom until May. This windy period gave rise to a total mixing of the water column and introduction of new nutrients to the photic zone (authors' unpubl. results). From February to April no stratification was detected and temperature was $10^{\circ} \mathrm{C}$ in the water column (Fig. 1). Chlorophyll a concentration was in the range of 1 to $2 \mu \mathrm{g} \mathrm{I}^{-1}$, and was dominated by the 2 smaller phytoplankton fractions $(0.2$ to $2 \mu \mathrm{m}$ and 2 to $10 \mu \mathrm{m})$, with brief increases of the latter fraction in April before the main bloom (Fig. 2). In May, a period of calm weather allowed a weak stratification of the water column to develop, while the temperature increased progressively up to $14^{\circ} \mathrm{C}$. On May 2 the spring bloom had developed and a subsurface chlorophyll a maximum of 


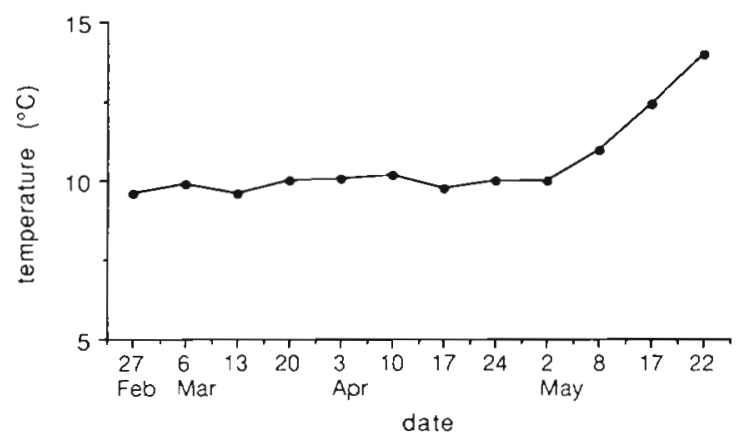

Fig. 1. Average temperature $\left({ }^{\circ} \mathrm{C}\right)$ in the photic layer at the sampling station
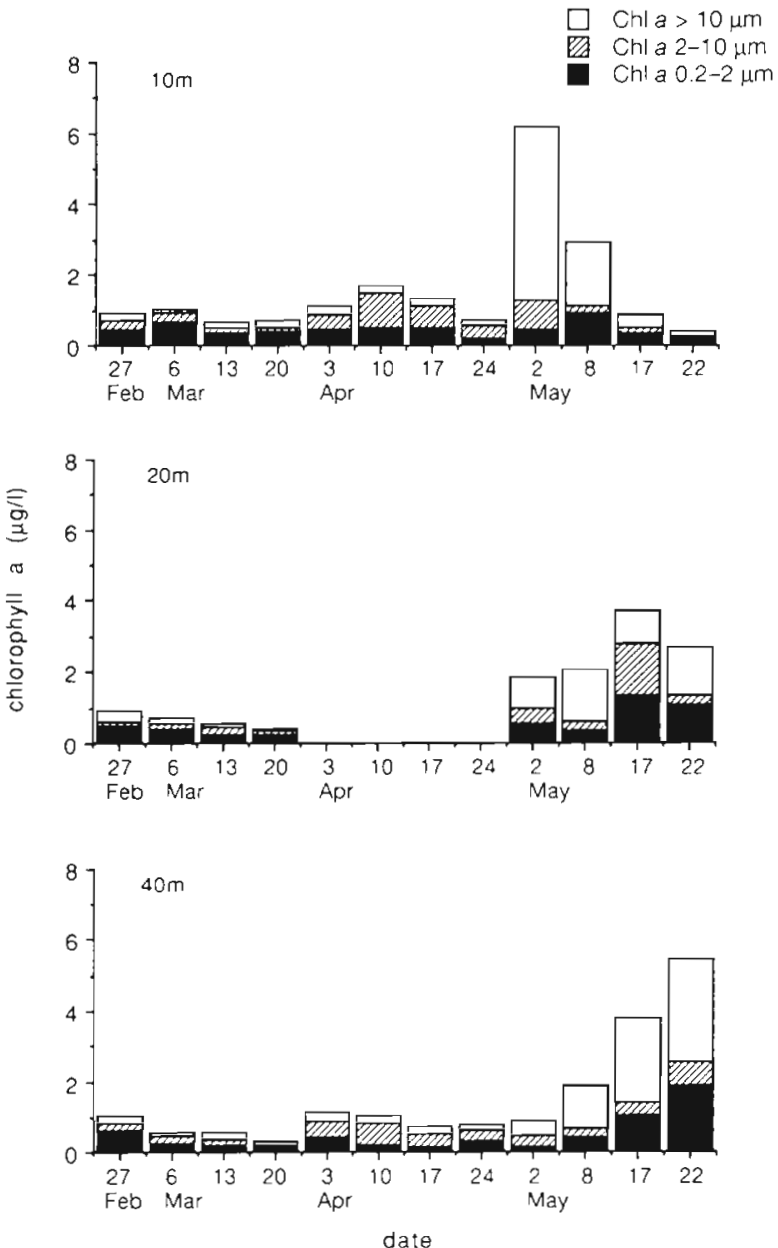

Fig. 2. Phytoplankton biomass (ug chlorophyll a $1^{-1}$ ), given as total and in the 3 size fractions: picoplankton 10.2 to $2 \mu \mathrm{m})$, nanoplankton (2 to $10 \mu \mathrm{m})$ and large phytoplankton (10 to 100 (um), at the 3 sampled depths
$6.5 \mu \mathrm{g} \mathrm{l^{-1 }}$ was attained at $10 \mathrm{~m}$. This phytoplankton bloom consisted mainly of larger cells (> $10 \mu \mathrm{m}$ ), predominantly diatoms, which increased by up to 10 times. This subsurface bloom sedimented in May, as indicated by the increase in chlorophyll a at $40 \mathrm{~m}$ depth.

\section{Copepod species composition and abundance}

Species composition was fairly constant throughout the study period, only changing with respect to relative abundances. The dominant copepods in the different size fractions were: Calanus helgolandicus, large size fraction; Pseudocalanus elongatus, medium; and the cyclopoid Oithona sp., small. Other relatively abundant species were Acartia clausi, Temora longicornis, Paracalanus parvus and Centropages typicus, all in the medium size fraction (Table 1). The abundance of most of these species increased to maximum values during April before the spring bloom, and Calanus helgolandicus increased again at the end of May. Overall, the medium size fraction dominated during the whole study period and Pseudocalanus elongatus was the most abundant species.

\section{Copepod gut pigment contents and ingestion rates}

Estimates of copepod gut pigment contents are shown in Fig. 3. Copepods of the small and medium size fractions showed low levels, which scarcely increased until the onset of the spring bloom in May. Their gut pigment contents then reached maximum levels in parallel with the increase of chlorophyll a concentration and dominance of larger-sized cells during the spring bloom, although the small copepods reached maximum 1 wk later than the medium ones. Copepods of the large size fraction showed higher levels, which increased progressively from April to May and also reached maximum during the spring bloom. These gut pigment contents were within the range of values reported in the literature (reviewed in Morales et al. 1990), and during the spring bloom tended to increase with the increases in copepod size and in phytoplankton concentration and cell size $(>10$ $\mu \mathrm{m})$. Their direct relationship with in situ chlorophyll a concentration has been reported previously (Nicolajsen et al. 1983, Dagg \& Walser 1987, Head et al. 1988) as well as their direct relationship with dominance of larger-sized cells (Head \& Harris 1987, Berggreen et al. 1988, Tiselius 1988, Dam \& Peterson 1991).

After the bloom, copepod gut contents decreased coincidentally with the decrease of phytoplankton concentration in the upper layer and its increase in deeper waters as a result of sinking 
Table 1. Abundances (ind $\mathrm{m}^{-3}$ ) of dominant species of 'potentially herbivorous' copepods in the 3 size fractions [large (>710 $\mu \mathrm{m}$ ), medium (350 to $710 \mu \mathrm{m})$ and small $(200$ to $350 \mu \mathrm{m})]$ within the upper $50 \mathrm{~m}$ of the water column

\begin{tabular}{|c|c|c|c|c|c|c|c|c|}
\hline $\begin{array}{l}\text { Date } \\
\text { (1989) }\end{array}$ & $\begin{array}{c}\text { Large } \\
\text { Calanus } \\
\text { helgolandicus }\end{array}$ & $\begin{array}{c}\text { Centropages } \\
\text { typicus }\end{array}$ & $\begin{array}{c}\text { Temora } \\
\text { longicornus }\end{array}$ & $\begin{array}{c}\text { Medium } \\
\text { Acartia } \\
\text { clausi }\end{array}$ & $\begin{array}{c}\text { Pseudocalanus } \\
\text { elongatus }\end{array}$ & $\begin{array}{c}\text { Paracalanus } \\
\text { parvus }\end{array}$ & $\begin{array}{l}\text { Oithona } \\
\text { sp. }\end{array}$ & $\begin{array}{l}\text { Small } \\
\text { Copepodites }\end{array}$ \\
\hline Feb 27 & 6 & 0 & 14 & 78 & 77 & 42 & 131 & 0 \\
\hline Mar 6 & 7 & 2 & 32 & 93 & 249 & 0 & 129 & 32 \\
\hline Mar 13 & 36 & 3 & 138 & 76 & 789 & 0 & 184 & 20 \\
\hline Mar 20 & 20 & 8 & 46 & 269 & 852 & 0 & 53 & 42 \\
\hline Apr 3 & 51 & 35 & 781 & 1554 & 3763 & 0 & 956 & 35 \\
\hline Apr 10 & 43 & 85 & 973 & 1255 & 2855 & 0 & 1268 & 34 \\
\hline Apr 17 & 54 & 11 & 740 & 642 & 2408 & 642 & 1088 & 0 \\
\hline Apr 24 & 44 & 44 & 1002 & 903 & 1912 & 820 & 1557 & 0 \\
\hline May 2 & 18 & 6 & 348 & 153 & 619 & 258 & 631 & 0 \\
\hline May 8 & 33 & 33 & 131 & 142 & 417 & 193 & 299 & 0 \\
\hline May 17 & 57 & 0 & 362 & 515 & 423 & 163 & 617 & 74 \\
\hline May 22 & 81 & 23 & 139 & 0 & 455 & 61 & 121 & 75 \\
\hline
\end{tabular}
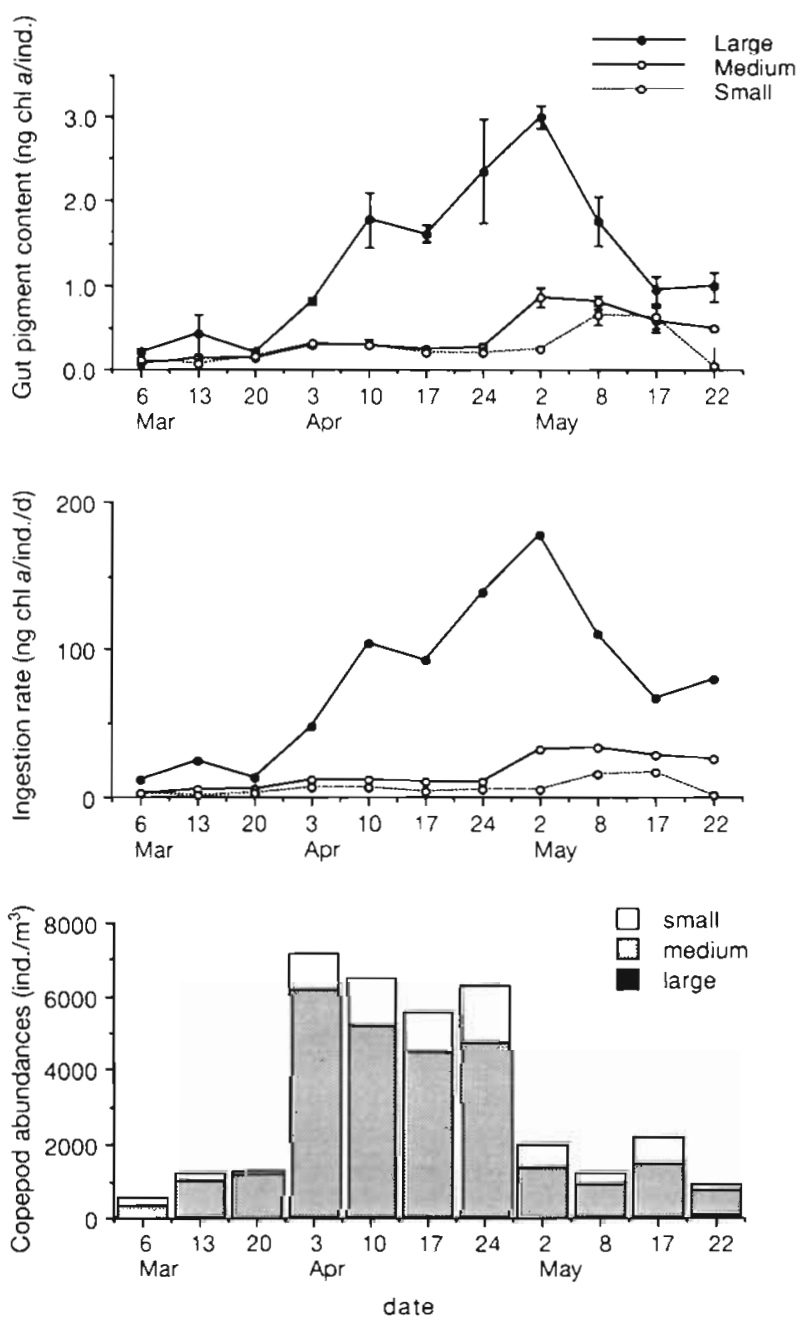

Fig. 3. Gut pigment contents ( $\mathrm{ng}$ chl $\mathrm{a}$ ind. ${ }^{-1}$ ), ingestion rates (ng chl $a$ ind ${ }^{-1} \mathrm{~d}^{-1}$ ) and abundances (ind. $\mathrm{m}^{-3}$ ) of the dominant 'herbivorous' species in the 3 copepod size fractions: large $(>710 \mu \mathrm{m})$, medium (350 to $710 \mu \mathrm{m})$ and small $(200$ to $350 \mu \mathrm{m})$
Results of the gut clearance experiments are shown in Table 2. The estimated clearance rate constants, although variable within each copepod size fraction, were within the range of published values (reviewed in Morales et al. 1990). The average values, after correcting for in situ temperature, were multiplied by the average gut contents per size fraction to obtain the individual ingestion rates per size fraction. The results are shown in Fig. 3. These ingestion rates showed a tendency similar to that of gut pigment contents, increasing with copepod body size and from winter to the spring phytoplankton bloom, in parallel with the increase in phytoplankton biomass and the change in the size distribution of phytoplankton towards largesized cells. These values were also within the range of copepod ingestion rates reported in the literature, based on the gut fluorescence method (Nicolajsen et al. 1983, Kiørboe et al. 1985, Tande \& Båmstedt 1985, Head \& Harris 1987, Kiørboe \& Tiselius 1987, Head et al. 1988, Peterson et al. 1990b).

\section{Copepod grazing rates and grazing impact}

To estimate the daily consumption of phytoplankton in the water column during the study period, daily ingestion rates were multiplied by the corresponding abundances of dominant copepods in the water column. The results in Table 3 reflect higher grazing rates in the weeks just before the spring bloom during the exponential growth phase of phytoplankton, mostly as a result of the increase in copepod abundance in that period (see Fig. 3). Table 3 also shows the importance of the medium size fraction in terms of phytoplankton consumption (accounting for 70 to $90 \%$ ).

The grazing impact of the copepod community on total chlorophyll a standing stock ranged from between 
Table 2. Estimates of gut clearance rate constants $(k)$ for the different size fractions of copepods, obtained by exponential regression analysis

\begin{tabular}{|c|c|c|c|c|c|}
\hline $\begin{array}{l}\text { Copepod } \\
\text { size fraction }\end{array}$ & $\begin{array}{l}\text { Temp. } \\
\left({ }^{\circ} \mathrm{C}\right)\end{array}$ & $\begin{array}{c}\text { Food } \\
\left(\mu g \text { chl } a l^{-1}\right)\end{array}$ & $\begin{array}{c}k \\
\left(\min ^{-1}\right)\end{array}$ & $r^{2}$ & Mean $k(S D)$ \\
\hline Large & 15 & $\begin{array}{l}18.9 \\
15.1 \\
16.1\end{array}$ & $\begin{array}{l}0.050^{\cdots} \\
0.076^{\circ} \\
0.058^{\cdots}\end{array}$ & $\begin{array}{l}0.789 \\
0.897 \\
0.772\end{array}$ & $0.061(0.013)$ \\
\hline Medium & 15 & $\begin{array}{r}18.9 \\
18.9 \\
6.4\end{array}$ & $\begin{array}{l}0.050^{\circ} \\
0.033^{\circ} \\
0.036^{\circ}\end{array}$ & $\begin{array}{l}0.743 \\
0.683 \\
0.305\end{array}$ & $0.040(0.009)$ \\
\hline Small & 15 & $\begin{array}{l}8.5 \\
8.5 \\
6.8\end{array}$ & $\begin{array}{l}0.027^{\cdots} \\
0.020^{\cdots} \\
0.021^{\cdots}\end{array}$ & $\begin{array}{l}0.343 \\
0.269 \\
0.618\end{array}$ & $0.023(0.004)$ \\
\hline
\end{tabular}

Table 3. Copepod grazing rates ( $\mathrm{mg} \mathrm{chl} \mathrm{a} \mathrm{m}^{-2} \mathrm{~d}^{-1}$ ) integrated over the water column $(50 \mathrm{~m})$

\begin{tabular}{|c|c|c|c|c|}
\hline \multirow{2}{*}{$\begin{array}{l}\text { Date } \\
(1989)\end{array}$} & \multicolumn{3}{|c|}{ Copepod size fraction } & \multirow{2}{*}{$\begin{array}{c}\text { Total } \\
\text { community }\end{array}$} \\
\hline & Large & Medium & Small & \\
\hline Mar 6 & 0.004 & 0.041 & 0.020 & 0.065 \\
\hline Mar 13 & 0.044 & 0.255 & 0.013 & 0.312 \\
\hline Mar 20 & 0.012 & 0.311 & 0.015 & 0.338 \\
\hline Apr 3 & 0.122 & 3.493 & 0.328 & 3.943 \\
\hline Apr 10 & 0.224 & 2.964 & 0.449 & 3.637 \\
\hline Apr 17 & 0.252 & 2.163 & 0.246 & 2.661 \\
\hline Apr 24 & 0.302 & 2.481 & 0.354 & 3.137 \\
\hline May 2 & 0.157 & 2.273 & 0.169 & 2.599 \\
\hline May 8 & 0.183 & 1.532 & 0.237 & 1.952 \\
\hline May 17 & 0.191 & 2.075 & 0.596 & 2.862 \\
\hline May 22 & 0.322 & 0.895 & 0.013 & 1.230 \\
\hline
\end{tabular}

Table 4. Grazing impact of copepod community, expressed as the percentage of the total phytoplankton standing stock, and of the fraction $>10 \mu \mathrm{m}$, grazed daily in the water column $(50 \mathrm{~m})$

\begin{tabular}{|c|c|c|c|c|}
\hline $\begin{array}{l}\text { Date } \\
\text { (1989) }\end{array}$ & $\begin{array}{c}\text { Total } \\
\text { chl a } \\
\left(\mathrm{mg} \mathrm{m}^{-2}\right)\end{array}$ & $\begin{array}{c}\text { Chl a } \\
>10 \mu \mathrm{m} \\
\left(\mathrm{mg} \mathrm{m}^{-2}\right)\end{array}$ & $\begin{array}{c}\% \text { Grazed } \\
\text { of total } \\
\operatorname{chl} a\end{array}$ & $\begin{array}{c}\% \text { Grazed } \\
\text { of chl } a \\
>10 \mu \mathrm{m}\end{array}$ \\
\hline Mar 6 & 38.95 & 6.15 & 0.17 & 1.06 \\
\hline Mar 13 & 30.70 & 8.25 & 1.02 & 3.78 \\
\hline $\operatorname{Mar} 20$ & 24.45 & 6.55 & 1.38 & 5.16 \\
\hline Apr 3 & 56.30 & 13.05 & 7.00 & 30.22 \\
\hline Apr 10 & 66.20 & 11.00 & 5.49 & 33.06 \\
\hline Apr 17 & 51.05 & 9.65 & 5.22 & 27.58 \\
\hline Apr 24 & 37.50 & 7.95 & 8.37 & 39.46 \\
\hline May 2 & 148.50 & 102.25 & 1.75 & 2.54 \\
\hline May 8 & 114.45 & 74.35 & 1.71 & 2.63 \\
\hline May 17 & 139.90 & 61.10 & 2.05 & 4.68 \\
\hline May 22 & 141.95 & 72.25 & 0.87 & 1.70 \\
\hline
\end{tabular}

5 and $8 \%$ during the exponential growth phase of phytoplankton (in the weeks prior to the spring bloom) to $<2 \%$ at other times. When the phytoplankton fraction $>10 \mu \mathrm{m}$ was considered as available food, the grazing impact accounted for 30 to $40 \%$ and $<5 \%$, respectively, for the same periods (Table 4). The medium-size-fraction copepods accounted for most of the community grazing impact on phytoplankton, as a result of their relative abundance.

\section{DISCUSSION}

After a period of rough weather with vertical mixing of the water column and input of nutrients, temporal stratification of the water column and increasing temperature gave rise to the phytoplankton bloom (mainly the fraction $>10 \mu \mathrm{m}$ ), which enhanced copepod grazing, increasing their gut pigment contents and ingestion rates.

Several authors have reported enhanced copepod feeding, growth and fecundity at spatio-temporal discontinuities in the water column structure, in parallel with chlorophyll a concentration peaks and dominance of large cells. This occurs in tidal fronts, upwellings, spring blooms and storm events (Hanson et al. 1986 , Peterson \& Bellantoni 1987, Kiorboe et al. 1988, 1990. Nielsen \& Kiørboe 1991, Peterson et al. 1991). The enhanced feeding activity of copepods seems to be mainly related to changes in phytoplankton size-distribution leading to dominance of larger cells, and so ultimately depends on vertical physical processes. However, the interpretation of their effects on the plankton is complicated because it is difficult to distinguish between the effects of advective processes and spatial heterogeneity. 
The difference observed in this study in the weeks before the spring bloom between the large size fraction of copepods, with a progressive increase in feeding rates, and the 2 smaller fractions, with low rates, suggests that these fractions have different strategies. It may reflect different migratory patterns related to copepod body size, as reported in the literature (Tiselius 1988, Peterson et al. 1990b). Thus larger copepods such as the dominant oceanic species Calanus helgolandicus undergo vertical migration, which allows them to move to different layers of water characterized by varying food concentrations. In contrast, smaller neritic copepods such as the dominant species Paracalanus parvus, Temora longicornis and Centropages typicus only migrate slightly or stay in the upper layer. Moreover, neritic and oceanic copepod species are adapted to different temporal and spatial scales of variation in their trophic environment, showing 2 different responses. More oceanic species can physiologically remove themselves from such fluctuations due to their lipidic storage, while more neritic species depend on constant food availability and are therefore more sensitive to variations in the food environment (Dagg 1977, Paffenhofer \& Stearns 1988, Båmstedt et al. 1990); this may also explain the quick response of neritic copepods to the phytoplankton bloom.

The present study is among the few that have attempted to estimate community grazing rates and grazing impact on phytoplankton by employing measurements of ingestion rates, copepod abundances and chlorophyll a concentration. Those which have reported estimates of grazing impact based on the gut fluorescence method have generally obtained very low percentages. Thus, Nicolajsen et al. (1983) reported daily grazing rates of $1 \%$ of phytoplankton standing stock during the spring bloom in the $\varnothing$ resund, Tiselius (1988) reported daily grazing rates of up to $4 \%$ of phytoplankton standing stock during summer in the Skagerrak and Kattegat, Peterson et al. (1990b) reported 1 to $5 \%$ of phytoplankton standing stock grazed daily in the southern Benguela upwelling, and Morales et al. (1991) reported $<1 \%$ in the North Atlantic.

Our results showed a daily grazing impact of the copepod community on total phytoplankton standing stock of 5 to $8 \%$ during the exponential growth phase of phytoplankton early in the spring bloom and $<2 \%$ in other periods, which agrees with the previously reported data cited above. But when only the phytoplankton size fraction $>10 \mu \mathrm{m}$ was considered as available food, the daily grazing impact increased up to $30-40 \%$ and $<5 \%$ respectively, results which are much higher than previously reported.

The variability in grazing impact during the study period was mainly a result of differences in both copepod abundances and copepod feeding rates. Although large copepods showed the highest daily ingestion rates on an individual basis, the overall highest phytoplankton consumption was by the mediumsized copepods, due to their numerical dominance.

These results support the idea of food limitation in coastal environments, mostly related to the food size structure. In coastal food webs, phytoplankton production is generally underexploited by copepod grazing and most of the enhanced phytoplankton production passes through other paths (microbial loop) or sediments to the bottom (Peinert et al. 1982, Smetacek 1984, Fenchel 1988, Jiménez et al. 1989). In the present study, this was the case when total phytoplankton biomass was taken into account, and also during the periods before and after the spring bloom when only the phytoplankton biomass $>10 \mu \mathrm{m}$ was considered, although it did not apply for the early spring bloom period, during which a relatively high proportion of larger-sized phytoplankton was grazed.

In any case, it is possible that all these data on copepod grazing impact are somehow underestimates. Several possible sources of error associated with the methods applied can be considered, some related to the estimation of copepod community ingestion rate and others to the estimation of available food.

Regarding the copepod community ingestion rate calculation, 2 possible sources of error are the estimation of ingestion rate using the gut fluorescence technique, and the estimation of copepod abundances.

The problems associated with applying the gut fluorescence technique to estimate ingestion rates have been discussed in depth by several authors. They are mostly related to: (1) diel rhythms in gut pigment contents (Mackas \& Bohrer 1976, Baars \& Oosterhuis 1984, Head et al. 1984, 1985, Simard et al. 1985, Dagg \& Walser 1987. Head \& Harris 1987. Bautista et al. 1988, Dagg et al. 1989); (2) possible pigment destruction in copepod guts (Conover et al. 1986, Wang \& Conover 1986, Dagg \& Walser 1987, Kiørboe \& Tiselius 1987. Dam \& Peterson 1988, Lopez et al. 1988, Peterson et al. 1990a); and (3) accurate estimation of the gut clearance rate constant (Kiørboe et al. 1982, Huntley et al. 1987. Kiørboe \& Tiselius 1987, Bautista et al. 1988, Dam \& Peterson 1988).

Gut pigment contents obtained in our study were based on single daily analyses, which could lead to underestimations if diel rhythms involving higher nocturnal feeding occurred. However, diel feeding rhythms are variable and do not always happen (Dagg \& Walser 1987, Head \& Harris 1987).

In addition, pigment destruction in copepod gut does occur, although reported values are highly variable (from 0 to $>100 \%$ ) and are not always real but attribut- 
able to experimental artifacts. An average value of $30 \%$ has been estimated (Dam \& Peterson 1988, Lopez et al. 1988). Finally, literature estimations of clearance rate constant are numerous and also show high variability (reviewed in Morales et al. 1990), which seems to be mostly related to environmental factors. Our estimations are within the reported range of values for copepod species of the same and similar body sizes, at similar temperatures.

Regarding the estimation of copepod abundances, the small size fraction of copepods only included those larger than $200 \mu \mathrm{m}$. Many copepodites and Oithona $\mathrm{sp}$. might have passed through the $200 \mu \mathrm{m}$ mesh filter and thus have not been considered in calculating grazing rates and grazing impact. However, the percentage of underestimation cannot be determined for the present data. The relative importance of this smaller fraction of copepods has been discussed by Morales et al. (1991), who used the same $200 \mathrm{um}$ mesh filter as a lower limit, obtaining similar values in the northeast Atlantic.

Finally, concerning the estimation of available food, only phytoplankton cells were taken into account. Few copepods are pure herbivorous, most are omnivorous, and heterotrophic flagellates, ciliates and nauplii may be an important food source at times (Lampitt \& Gamble 1982, Tiselius 1989). Another relevant question is: what sizes of cells are grazed? In our study, the available food was estimated both as total chlorophyll $a$ and as chlorophyll $a>10 \mu \mathrm{m}$. Several studies have pointed out that planktonic copepods prefer to feed on cells larger than 5 to $10 \mu \mathrm{m}$ (Harris 1982, Berggreen et al. 1988, Tiselius 1988, Dam \& Peterson 1991). Our results showed an increase in copepod ingestion when the phytoplankton fraction $>10 \mu \mathrm{m}$ increased during the spring bloom. When only this larger fraction of phytoplankton was considered for estimating grazing impact of the copepod community, this accounted for up to $30-40 \%$. This grazing impact might be still higher if we correct it for possible diel rhythms, pigment destruction in copepod guts and abundance of the small size fraction of copepods, as discussed above.

Despite these uncertainties, our results suggest that in this region and at this time, the copepod community was not able to assimilate most of the enhanced phytoplankton production, except early in the spring bloom period when grazing impact accounted for 30 to $40 \%$ of the chlorophyll $a>10 \mathrm{um}$. It is possible that during other periods, for instance summer, when the biomass of copepods increases and food becomes more limited, a higher proportion of the phytoplankton biomass is grazed by the copepod community and channelled to higher trophic levels in the pelagic food web.

Acknowledgements. We are grateful to the crew of the RV 'Sepia' and R. Head for assistance with sampling during this study and to P. R. G. Tranter for zooplankton counting. This work was supported by a contract from the Ministry of Agriculture, Fisheries and Food (UK) and a postdoctoral fellowship to B. Bautista from the Ministerio de Educación y Ciencia (Spain).

\section{LITERATURE CITED}

Baars, M. A., Oosterhuis, S. S. (1984). Diurnal feeding rhythms in North Sea copepods measured by gut fluorescence, digestive enzyme activity and grazing on labelled food. Neth. J. Sea Res. 18: 97-119

Båmstedt, U., Hakanson, J. L., Brenner-Larsen, J., Bjornsen, P. K., Geertz-Hansen, O., Tiselius, P. (1990). Copepod nutritional condition and the pelagic production during autumn in Kosterfjorden, western Sweden. Mar. Biol. 104: 197-208

Bartram, W. C. (1980). Experimental development of a model for the feeding of neritic copepods on phytoplankton. J. Plankton Res. 3: 25-51

Bautista, B., Rodriguez, V., Jiménez, F. (1988). Short-term feeding rates of Acartia grani in natural conditions: diurnal variation. J. Plankton Res, 10 (5): 907-920

Berggreen, U., Hansen, B., Kiørboe, T (1988). Food size spectra, ingestion and growth of the copepod Acartia tonsa during development: implications for determination of copepod production. Mar Biol. 99: 341-352

Conover, R. J., Durvasula, R., Roy, S., Wang, R. (1986). Probable loss of chlorophyll-derived pigments during passage through the gut of zooplankton, and some of the consequences. Limnol. Oceanogr. 31 878-887

Cushing, D. H. (1989). A difference in structure between ecosystems in strongly stratified waters and those that are only weakly stratified. J. Plankton Res. 11: 1-3

Dagg, M. J. (1977). Some effects of patchy food environments on copepods. Limnol. Oceanogr 34:1062-1071

Dagg, M. J., Frost, B. W., Walser, J. E. Jr (1989). Copepod diel migration, feeding, and the vertical flux of phaeopigments. Limnol. Oceanogr. 34: 1062-107 1

Dagg, M. J., Walser, W E. Ir (1987). Ingestion, gut passage, and egestion by the copepod Neocalanus plumchrus in the laboratory and in the subartic Pacific Ocean. Limnol Oceanogr. 32: 178-188

Dam, H. G., Peterson, W. T (1988). The effect of temperature on the gut clearance rate constant of planktonic copepods J. exp. Mar Biol. Ecol. 123: 1-14

Dam, H. G. Peterson, W. T (1991). In situ feeding behavior of the copepod Temora longicornis: effects of seasonal changes in chlorophyll size fractions and female size. Mar Ecol. Prog. Ser. 71. 113-123

Dam, H. G., Peterson, W. T., Okubo, A. (1991). A simple mathematical analysis of the limitations to inferring feeding behavior of zooplankton from gut content. Mar Ecol. Prog. Ser 69: 41-51

Fenchel, T (1988). Marine plankton food chains. Ann. Rev Ecol. Syst. 19: 19-38

Frost, B. W (1984). Utilization of phytoplankton production in the surface layer. In: Global Ocean Flux Study, Proceedings of a Workshop, September, 1984. National Academy Press, Washington, D.C., p. 125-135

Hanson, R. B., Alvarez-Ossorio, M. T., Cal, R., Campos, M. J., Roman, M. R., Santiago, G. Varela, M., Yoder, J. A. (1986). Plankton response following a spring upwelling event in Ria de Arosa, Spain. Mar. Ecol. Prog. Ser. 32: 101-113

Harris, R. P. (1982). Comparison of the feeding behavior of Calanus and Pseudocalanus in two experimentally manipulated enclosed systems. J. Mar. Biol. Ass. U.K. 62: 71-91 
Harris, G. P., Ganf, G. G., Thomas, D. P. (1987). Productivity, growth rates and cell size distributions of phytoplankton in the SW Tasman Sea: implications for carbon metabolism in the photic zone. J. Plankton Res. 9: 1003-1030

Head, E. J. H. (1986). Estimation of Arctic copepod grazing rates in vivo and comparison with in vitro methods. Mar Biol. 92: 371-379

Head, E. J. H., Bedo, A., Harris, L. R. (1988). Grazing, defecation and excretion rates of copepods from inter-island channels of the Canadian Arctic archipelago. Mar. Biol. 99: $333-340$

Head, E. J. H., Harris, L. R. (1987). Copepod feeding patterns before and during a spring bloom in Bedford Basin, Nova Scotia. Mar. Ecol. Prog. Ser 40: 221-230

Head, E. J. H., Harris, L. R., Abou Debs, C. (1985). Effect of daylength and food concentration on in situ diurnal feeding rhythms in Arctic copepods. Mar. Ecol. Prog. Ser 24: $281-288$

Head, E. J. H., Wang, R., Conover, R. J. (1984). Comparison of diumal feeding rhythms in Temora longicornis and Centropages hamatus with digestive enzyme activity. J. Plankton Res. 6: 543-551

Holligan, P. M., Harris, R. P., Newell, R. C., Harbour, D. S., Head, R. W., Lindley, E. A. S., Lucas, M. I., Tranter, P. R. G., Weekley, C. M. (1984). The vertical distribution and partitioning of organ carbon in mixed, frontal and stratified waters in the English Channel. Mar Ecol. Prog. Ser 14: $111-127$

Huntley, M. E., Marin, V., Escritor, F. (1987). Zooplankton grazers as transformers of ocean optics. J. mar. Res. 45: 911-945

Jimenez, F., Rodrıguez, J., Jiménez-Gómez, F., Bautista, B. (1989). Bottlenecks in the propagation of a fluctuation up the planktonic size spectrum in Mediterranean coastal waters. In: Ros, J. D. (ed.) Topics in marine biology. Scient. mar. 53(2-3): 269-275

Kiørboe, T., Kaas, H., Kruse, B., Møhlenberg, F., Tiselius, P., Aertebjerg, G. (1990). The structure of the pelagic food web in relation to water column structure in the Skagerrak. Mar. Ecol. Prog. Ser. 59: 19-32

Kiørboe, T., Møhlenberg, F., Nicolajsen, H. (1982). Ingestion rate and gut clearance in the copepod Centropages hamatus (Lilleborg) in relation to food concentration and temperature. Ophelia 21: 181-194

Kiørboe, T., Mohlenberg, F., Riisgard, H. V (1985). In situ feeding rates of planktonic copepods: a comparison of four methods. J. exp. mar. Biol. Ecol. 88: 67-81

Kiørboe, T., Mohlenberg, F., Tiselius, P. T. (1988). Propagation in planktonic copepods: production and mortality of eggs. Hydrobiologia 167/168: 219-225

Kiørboe, T., Tiselius, P. I (1987). Gut clearance and pigment destruction in a herbivorous copepod, Acartia tonsa, and the determination of in situ ingestion rates. J. Plankton Res. 9: 525-534

Kleppel, G. S., Pieper, R. E., Trager, G. (1988). Variability in the gut contents of individual Acartia tonsa from waters off southern California. Mar Biol. 97: 185-190

Lampitt, R. S., Gamble, J. S. (1982). Diet and respiration of Oithona nana. Mar Biol. 66: 85-191

Landry, M. R. (1977). A review of important concepts in the trophic organization of pelagic ecosystems. Helgoländer wiss. Meeresunters. 30: 8-17

Legendre, L. (1981). Hydrodynamic control of marine phytoplankton production: the paradox of stability. In: Nihoul, J. C. J. (ed.) Ecohydrodynamics. Proc. 12th Int. Liege Colloquium on Ocean Hydrodynamics. Elsevier, Amsterdam, p. $191-207$
López, M. D. G., Huntley, M. E., Sykes, P. F. (1988). Pigment destruction by Calanus pacificus: impact on the estimation of water column fluxes. J. Plankton Res. 10: $715-734$

Mackas, D. L., Bohrer, R. (1976). Fluorescence analysis of zooplankton gut contents and an investigation of diel feeding patterns. J. exp. mar. Biol. Ecol. 25: 77 -85

Morales, C. E., Bautista, B., Harris, R. P. (1990). Estimates of ingestion in copepod assemblages: gut fluorescence in relation to body size. In: Barnes, M., Gibson, R. N. (eds.) Trophic relationships in the marine environment. Aberdeen Univ. Press, Aberdeen, p. 565-577

Morales, C. E., Bedo, A., Harris, R. P., Tranter, P. R. G. (1991) Grazing of copepod assemblages in the north-east Atlantic: the importance of the small size fraction. J. Plankton Res. 13(2): 455-472

Nicolajsen, H., Mohlenberg, F., Kiørboe, T (1983). Algal grazing by the planktonic copepods Centropages hamatus and Pseudocalanus spp.: diurnal and seasonal variation during the spring phytoplankton bloom in the Oreesund. Ophelia 22: $15-31$

Nielsen, T G., Kiorboe, T (1991). Effects of a storm event on the structure of the pelagic food web with special emphasis on planktonic ciliates. J. Plankton Res. 13(1): 35-51

Paffenhöfer, G. A. (1984). Food ingestion by the marine planktonic copepod Paracalanus in relation to abundance and size distribution of food. Mar Biol. 80: 323-333

Paffenhöfer, G. A., Stearns, D. E. (1988). Why is Acartia tonsa (Copepoda: Calanoida) restricted to nearshore environments? Mar Ecol. Prog. Ser. 42(1): 33-38

Peinert, R., Saure, A., Stegmann, P., Stienen, C., Haardt, H. Smetacek, V. (1982). Dynamics of primary production in a coastal ecosystem. Neth. J. Sea Res. 16: 276-289

Peters, R. H., Downing, J. A. (1984). Empirical analysis of zooplankton filtering and feeding rates. Limnol. Oceanogr. 29: 763-784

Peterson, W. T., Bellantoni, D. C. (1987). Relationship between water column stratification, phytoplankton cell size and copepod fecundity in Long Island Sound and off central Chile. S. A.fr. J. mar Sci. 5: 411-421

Peterson, W. T., Painting, S. J., Barlow, R. (1990a). Feeding rates of Calanoides carinatus: a comparison of five methods including evaluation of the gut fluorescence method. Mar. Ecol. Prog. Ser. 63: 85-92

Peterson, W. T., Painting, S. J., Hutchings, L. (1990b). Diel variations in gut pigment content, diel vertical migration and estimates of grazing impact for copepods in the southern Benguela upwelling region in October 1987. J. Plankton Res. 12(2): 259-281

Peterson, W. T., Tiselius, P., Kiorboe, T (1991). Copepod egg production, moulting and growth rates, and secondary production. in the Skagerrak in August 1988. J. Plankton Res. 13(1): 131-154

Simard, Y., Lacroix, G., Legendre, L. (1985). In situ twilight grazing rhythm during diel vertical migration of a scattering layer of Calanus finmarchicus. Limnol. Oceanogr. 30: 598-606

Smetacek, V (1984). The food supply to the benthos. In: Fasham, M. J. (ed.) Flows of energy and materials in marine ecosystems: theory and practice. Plenum Press New York, p. 517-548

Strickland, J. D. H., Parsons, T R. (1972). A practical handbook of seawater analysis, 2nd edn. Bull. Fish. Res. Bd Can. 167: 1-310

Tande, K. S., Bămstedt, U. (1985). Grazing rates of the copepods Calanus glacialis and $C$. finmarchicus in arctic waters of the Barents Sea. Mar. Biol. 87: 251-258 
Tiselius, P. T. (1988). Effects of diurnal feeding rhythms species composition and vertical migration on the grazing impact of calanoid copepods in the Skagerrak and Kattegat. Ophelia 28: 215-230

Tiselius, P. T. (1989). Contribution of alloricate ciliates to the

This article was submitted to the editor diet of Acartia clausi and Centropages hamatus in coastal water. Mar. Ecol. Prog. Ser. 56: 49-56

Wang, R., Conover, R. J. (1986). Dynamics of gut pigment in the copepod Temora longicornis and the determination of in situ grazing rates. Limnol. Oceanogr. 31 867-877

Manuscript first received: July 22, 1991

Revised version accepted: February 26, 1992 